\title{
THE METAMORPHOSES IN THE CONCEPT OF THE CITY
}

\author{
as metamorfoses do conceito de cidade
}

\author{
Pedro de Almeida Vasconcelos *
}

\begin{abstract}
Resumo
O texto inicia com quatro questões preliminares e segue com as definições etimológicas das palavras cidade, urbano e aglomeração. Na parte principal do texto, a produção do conceito de cidade é examinada à partir de textos originais de autores escolhidos, apresentados em seis períodos ao longo dos séculos XIX e XX: (1) O período pré-acadêmico (1810-1869); (2) O período da institucionalização das ciências sociais (1870-1923); (3) O período entre as guerras mundiais (1914-1944); (4) O período do pós-guerra, dos "30 anos gloriosos" (1945-1972); (5) O período do início da crise atual (1973-1994); (6) O período atual (1995-2015). Nas Considerações Finais é levantada a questão da pertinência de denominar "cidade", fenômenos complexos tão diversos em diferentes tempos e espaços.
\end{abstract}

Palavras-Chave: Conceito; Cidade; Espaço urbano; Períodos.

\begin{abstract}
The text starts with four preliminary issues followed by the etymological definition of the words city, urban and agglomeration. In the main part of the text the production of the concept of city is examined in original texts of selected authors, presented in six periods over the nineteenth and twentieth centuries: (1) pre-academic period (1810-1869); (2) period of institutionalization of the social sciences (1870-1923); (3) period between the world wars (1914-1944); (4) post-war period, the "glorious 30 years" (1945-1972); (5) period from the beginning of the current crisis (1973-1994); (6) current period (1995-2015). In the final considerations the question is raised about the appropriateness of referring to the word "city" for complex phenomena so diverse in different times and spaces.
\end{abstract}

Key words: Concept; City; Urban space; Periods

\section{Résumé}

Le texte commence par quatre questions préliminaires suivies par les définitions étymologiques des mots ville, urbain et agglomération. La production du concept de la ville est analysée à partir de textes originaux d'auteurs choisis et est présentée dans le corps du texte en six périodes le long des du XIXème et XXème siècles: (1) La période pré-académique (1810-1869); (2) La période de l'institutionalisation des sciences sociales (1870-1923); (3) La période de l'entre-deux-guerres (1914-1944); (4) La période de l'après guerre, des "30 glorieuses" (1945-1972); (5) La période du début de la crise actuelle (1973-1994); (6) La période actuelle (1995-2015). Dans les Considérations Finales, la pertinence de la dénomination de "ville" pour des phénomènes complexes aussi divers en diférents temps et espaces est questionnée.

Mots-clés: Concepts; Ville; Espace urbain; Périodes.

(*) Lecturer, Doctor of the Federal University of Bahia (Universidade Federal da Bahia) - Rua Barão de Geremoabo, s/n, CEP:40170-290, Salvador (BA), Brasil. Tel: (+55 71) 32838569 - pavascon@uol.com.br 


\section{INTRODUCTION}

Discussing the transformations in the concept of the city at a symposium on Urban Geography is fundamental, but some preliminary questions need to be asked.

First, there are political issues that are not fully disclosed, such as the demand made by the editor of the Hachette to Elisée Reclus that he should "not give his political opinions" when writing the 19 volumes of Nouvelle Géographie universelle, la terre et les hommes, whilst in L'Homme et la Terre, where the urban theme is emphasized, the author was free from these requirements (Pelletier, 2010, p. 10-11).

Secondly the historical context must be taken into account, sometimes with an explanation, as in the case of the North American urbanist historian Lewis Mumford, who in his work of 1938 proposed that the notion of "Tyrannopolis" "where the gangster dictators like Hitler and Mussolini would appear" (1945, p. 122-123). However, most of the time, it is not clear with whom the author is speaking.

In third place it is necessary to verify in which geographical (and temporal) space the concept was elaborated. An interesting example is that of Francesco Indovina when he proposed the concept of the "Diffuse City", showing that the phenomena had some similarities to North American suburbs but "could be considered the Italian (European?) response to problems that on the American continent gave way to this very particular form of spatial organization" (2004, p. 50).

Finally, I would like to highlight the issues raised by my colleague Cesar Costa Gomes: the importance of observation in the Social Sciences ("that has often been relegated to a lower plane"); considering the themes constructed as a "succession of general and generic affirmations"; and, above all, the height of the censure, without "room for doubt or even investigation" (Gomes, 2013, IX).

In fact, we all know what a city is, although it is difficult to define. The general public, including journalists and politicians, still confuse city with municipality, for example.

The word city comes from the Latin civitate a notion close to civitas, which is the origin of the words citizen and civilization. The word urban comes from the Latin urbs that also means city, whereas the Greek word polis, city, and politicos, of the city, are the origin of the work politics. Finally, the concept of agglomeration comes from the Latin glomus, glomero and means a ball or shaped in to a ball (Lacoste, 2005, p. 21, 80, 315).

The production of concepts about the city can be divided into six periods. For each period we will highlight the attempts to conceptualize the city by authors from different disciplines or even non-academic authors.

\section{THE PRE-ACADEMIC PERIOD (1810-1869)}

In the book The German Ideology (1846), a joint work by Karl Marx and Friedrich Engels, the authors make a first definition of the city as "the reality of the concentration of the population, the instruments of production, capital, pleasure, necessities [...]"(p. 64). Perhaps the interest in the subject came more from Engels, bearing in mind the publication in the previous year of the book The Condition of the Working Class in England, in which he described the city of London and above all the precarious conditions of workers in Manchester.

Ildefonso Cerdá, the author of the expansion plans for Barcelona, in his work Teoria General de la Urbanización (1867), introduced the concept of urbanization by defining cities as “[...] very poorly assembled fragments of past eras" (p. 169).

In Germany, the geographer Friedrich Ratzel, in his book Antropogeographie, of 1882, proposed the following definition of a city: "a continuous densification of people and human dwellings, which occupies a considerable area of land and is located in the center of the main lines of trade". 
Ferdinand Tonnies, in his book Community and Society of 1887, even mentioned the existence of a "world city", which would contain the essence of a whole group of peoples.

The historian Paul Meuriot, in his 1897 thesis Urban agglomerations in contemporary Europe, preferred to work with the concept of urban agglomeration, which would be "the meeting in a relatively small space of a more or less considerable population" that would be characterized by diversity (Apud Vasconcelos, 2012, p. 92-03).

The sociologist René Maunier, in his thesis of 1910, The origin and economic function of cities, tried to establish the difference between simple and homogenous physical space and differentiated and heterogeneous social space (p. 13), defining social space as the "society's projection into the physical space it occupies" (p. 14) and the city as "a complex society whose geographical base is particularly restricted in relation to its volume [...]"(p. 44), within the conception of social morphology.

Max Weber, who wrote his text on the city between 1910-1913, which was published posthumously, proposed in the first chapter "The concept of the city and the categories of cities" the definition of a "Urban Community", which should have a predominantly industrial and commercial character with the following characteristics: fortifications, a market, its own tribunal, correspondent forms of association and at least partial autonomy, which is a specifically Western phenomena, not found in the Ancient World or Eastern cities.

\section{THE INTERWAR PERIOD (1914-1944)}

In 1916 Robert Ezra Park, founder of the Chicago School of Urban Sociology, published the text "The City: Suggestions for the Investigation of Human Behavior in the Urban Environment" republished in the book The City in 1925, affirmed that "The city is [...] a state of mind, a body of customs and traditions, and of the organized attitudes and sentiments that inhere in these customs and are transmitted with this tradition." (p. 1)

The North American architect Frank Lloyd Wright, in his book The Disappearing City, of 1932, proposed the idea of the Broadacre City, that is, a dispersed city, in which each family would have a minimum lot of one acre (approximately 4,000 $\mathrm{m}^{2}$ ), structured in a super highway, with at least six lanes and three-lane secondary roads (p. 94) where the automobile would reign.

Louis Wirth, one of the main sociologists at the Chicago School, became known for his classic article "Urbanism as a way of life", of 1938, in which he aimed to create a sociological definition of the city, from a limited number of basic categories, that is, as a relatively large, dense and permanent nucleus of socially heterogenic individuals.

In the same year the urbanist historian Lewis Mumford provided a rich definition of the city in his book The Culture of Cities as a "[...] geographical plexus, an economic organization, an institutional process, a theatre of social action and an aesthetic symbol of a collective unit" (p. 433).

\section{THE POSTWAR PERIOD, THE “30 GLORIOUS YEARS” (1945-1972)}

Another North American urbanist, Kevin Lynch in his book Image of the City, of 1960, affirmed from a phenomenological perspective that the city "exists farther than the eye can see, more than the ear can hear" (p. 11).

In the geographer Jean Gottmann's book Megalopolis of 1961, it would be defined as an urbanized area with a nebulous structure; the result of exceptional growth and a pioneering area. This case deals with the gigantic urban-regional grouping linking several metropolises from Boston to Washington in the United States. 
The philosopher Henri Lefebvre was one of the intellectuals who studied cities the most, a secondary theme in Philosophy. In his famous book The Right to the City, of 1968, he defined the city as "a projection of society over the land" (p. 64). In his book The Urban Revolution of 1970, he affirmed that "we do not see the urban (urban space, the urban landscape)" (p. 43). The urban "is a pure form: the meeting point, the place for meetings, simultaneity" (p. 159).

The Spanish sociologist Manuel Castells published the classic The Urban Question in 1972, within the Marxist-structuralist conception. In this book he defined space as "a material product, in relation to other material elements [...] that give space [...] a form, a function, a social meaning" (p. 152) and that urban space is structured (p. 153). He also considered "the space of production is the regional space and the [space] of reproduction is called urban space" (p. 476), which he corrected in his postscript of 1975. Finally, he defined urban structure as a "concept that specifies the articulation of the fundamental instances of the social structure inside the urban units under consideration" (p. 477).

\section{THE PERIOD OF THE START OF THE CURRENT CRISES (1973-1994)}

More recently, the definitions of the city have varied depending on the tendency to which the author is linked, such as the English geographer David Harvey (1973), for whom the city was a "[...] complex, dynamic system in which the spatial form and the social process are in a continuous interaction" (p. 34). Subsequently, the same author moved to the socialist paradigm and considered the city as "the place of accumulated contradictions" (p. 174).

Since 1980 Jean Bastié and Bernard Dezert have proposed that the notion of the city should be substituted by "urban space", which they define as "a geometric space, but also a physical space, a space-time, an economic space, a social space and a perceived and lived space" (p. 39).

The geographer Paul Claval published the book La logique des villes in 1981; and he starts from the idea that the city is "[...] an organization designed to maximize social interaction" (p. 4). Urbanism finds its dynamism in the need for interaction (p. 53), which is examined together with communication and centrality (p. 56). In 1988 in the Dictionnaire de l'urbanisme et de l'aménagement he adds that three conditions are indispensable for establishing a city: the agglomeration of buildings; certain social characteristics of the population and a certain size (p. 706).

The Brazilian geographer Roberto Lobato Correia (1989), defined urban space as a "fragmented and articulated space, reflection and social conditioning, a set of symbols and fields of struggles" (p. 9), in his book O Espaço Urbano.

In 1989 Manuel Castells published the book Informational City, with the subtitle "Information technologies, economic restructuring and the regional urban process", in which he announces the "the historical emergence of a space of flows, surpassing the significance of the space of places" (p. 483). However, he does not define city and works with the concept of a "dual city", whose spatial structure combines segregation, diversity and hierarchy (p. 320).

For the geographer Marcel Roncayolo (1990) the city "is a particular territory or a combination of territories" and the city also organizes a territory or a system of relations (p. 20). To study cities the population, functions, culture, morphology, the social division and the functional division of the urban space, politics and territories should all be analyzed.

Also in 1990 the urbanist Francesco Indovina proposed the concept of the diffuse city, characterized by a consistent mass of population, services and productive activities; dispersion over a vast territory; and a high connection between distinct points in the territory.

In the book The Global City (1991) by the sociologist Saskia Sassen the global city is conceptualized as an agglomeration of core functions in a few cities in a globalized economy, when the author discusses the global cities of New York, London and Tokyo. We could ask whether the better definition would be Global Metropolis? 
For Brunet et al. in their dictionary Les mots de la géographie (1993) the city is defined as "an agglomeration of properties and persons of some importance that originally distinguishes itself from the agricultural field". However, the city also brings together people who fundamentally live off of trade and services. Above all, it is "the place where civilization was created, or where information, formation and innovation are developed". The city is also the location for the accumulation of wealth (p. 508). Urban geography would study urban space and urban networks (p. 509).

In 1994 the Brazilian geographer Milton Santos established the difference between urban, which is frequently abstract, general and external, and the city, which is particular, concrete and internal (p. 69). To the author the city is at the same time, a region and a place (p. 71).

\section{THE CURRENT PERIOD (1995-2015)}

In the late French urbanist François Ascher's book Métapolis of 1995, there is an examination of the new spatial forms that would exceed and encompass the existing metropolises, in an analysis on the border between the urban and regional.

Also noteworthy is the book The Postmodern City (1997) by the Italian Giandomenico Amendola; it is probably the best critique of the new theme. He gives other suggested appellations that seek to name the results of the current de-urbanization and de-localization: Outer Cities; Technopoles; Technoburbs; Silicon Landscape; Metroplex; and 100 Miles City.

In Christine Boyer's book Cybercities of 1996, Cybercities are defined as "This unwieldy mixture of urban dystopia and cyberspace [...] states [...] a profound mutation has taken place [...] a transformation from the machine city of modernism to the informational city of postmodernism." (p. 14). The Cybercities would also correspond to a narrative of the dematerialization of physical space and chronological time (p. 18) .

For Zoildo et al., authors of the Diccionario de geografia urbana, urbanismo y ordenación del território (2000), the city is a "Population nucleus of certain dimensions and specialized functions in an ample territory" (p. 78), whilst urban agglomeration would be a "form of land occupation in which a principle city, affected by rapid growth, creates the emergence of a metropolitan crown in its surroundings" (p. 20).

Edward Soja, in his book Postmetropolis, of 2000, distinguishes six discourses about the postmetropolis that can synthesize the current debate about cities: (1) The Postfordist Industrial Metropolis; (2) The Globalization of Cityspace; (3) The Restructuring of Urban Form; (4) The Fractal City: [...] the Restructured Social Mosaic; (5) Governing Space in the Postmetropolis; (6) Restructuring the Urban Imaginary .

In the Dictionnaire La ville et l'urbain (2006), the French geographer Denise Pumain characterized the city as "a densely inhabited environment, characterized by a differentiated society, a functional diversity, a capitalization and capacity for innovation that are inscribed in multiple networks of interaction and that form a hierarchy, that include more and more complex knots that go from the smallest to the largest cities" (2006, p. 303).

The debate about the city can be concluded by commenting on the book L'Aventure des mots de la ville, by Topalov et al. (2010), 1,493 pages long, containing 264 articles, written by 160 authors in eight languages (German, Arabic, Spanish, French, English, Italian, Portuguese and Russian), which demonstrates the richness and the vastness of the theme. The different works and their translation into the languages cited above also confirm the diversity of this universal phenomenon: cidade (Portuguese), città (Italian), city, town (English), ciudad (Spanish), gorod (Russian) medina (Arabic) stadt (German), and ville (French) 


\section{FINAL CONSIDERATIONS}

For a world in which space and distances are changing in value, we can ask if it still makes sense to call city the diverse complex phenomenon that are found in different historical and geographical contexts.

Therefore, the historical periods, the geographical locations and qualifications of the author should be taken into account.

Are medieval cities with walls separating them from the countryside and current metropolises with undefined limits the same thing? Are the dispersed North American cities, the concentrated European cities, the unequal Brazilian cities the same, without even mentioning African and Asian cities?

\section{BIBLIOGRAPHIC REFERENCE}

AMENDOLA, Giandomenico. La Ciudad Postmoderna (1997). Madrid: Celeste, 2000.

ASCHER, François. Métapolis ou l'avenir des villes. Paris: O. Jacob, 1995.

BASTIÉ, J.; DEZERT, B. L'espace urbain. Paris: Masson, 1980.

BRUNET, Roger et al. Les mots de la géographie. Paris : Reclus, 1993.

BOYER, Christine. CyberCities. New York : Princeton Architectural Press, 1996.

CASTELLS, Manuel. La question urbaine (1972). Paris: François Maspero, 1977.

CASTELLS, Manuel. La Ciudad Informaconal. Madrid: Alianza, 1995 [1989].

CERDÁ y SUNYER, Ildefonso. La Théorie générale de l'urbanisation. Paris : Seuil, 1979 [1867].

CLAVAL, Paul. La logique des villes. Essai d'urbanologie. Paris: Litec, 1981.7

CLAVAL, Paul. Ville. In: MERLIN, P.; CHOAY, F. (Dir.) Dictionnaire de l'urbanisme et de l'aménagement. Paris, P.U.F., 2008, p. 706.

CORREA, Roberto Lobato. O Espaço Urbano. São Paulo: Ática, 1989.

GOMES, Paulo Cesar da Costa. Prefácio, in SPOSITO, M. E. B.; GOES, E. M. Espaços Fechados e Cidades. São Paulo, UNESP, 2013, p. IX-X.

GOTTMANN, Jean. Megalopolis, or the Urbanization of the Northeastern Seaborn [1957]. In: Mayer; Koh, (Ed.) Readings in Urban Geography. Chicago: Univ. of Chicago Press, 1959, p.46-56.

HARVEY, David. A Justiça Social e a Cidade. São Paulo: Hucitec, 1980 [1973].

INDOVINA, Francesco. La ciudad difusa. In MARTIN RAMOS (ed.) Lo urbano en 20 autores contemporáneos. Barcelona: Edicions UPC; ETSAB, 2004, p. 49-59.

LACOSTE, Yves. Dicionário de Geografia. Lisboa, Teorema, 2005 [2003].

LEFEBVRE, Henri. La révolution urbaine. Paris: Gallimard, 1970.

LEFEBVRE, Henri. Le droit à la ville (1968). Paris: Anthropos, 1972.

LYNCH, K. A Imagem da Cidade. Lisboa: Eds. 70, 1988 [1960].

MARX, K.; ENGELS, F. A Ideologia Alemã (1846). São Paulo: Moraes, 1984.

MAUNIER, René. L'origine et le fonction économique des villes. Paris, L'Harmattan, 2004 [1910].

MUMFORD, L. La Cultura de las Ciudades. Buenos Aires : Emecé, 1945 [1938].

PARK, Robert E. The City: Suggestions for the Investigation of Human Behavior in the Urban Enrivonnement. In PARK, R. E. ; BURGESS, E. W. (Org.) The City. Chicago, University of Chicago Press, 1976, p. 1-46 [1916].

PELLETIER, Philippe. A Cidade e a Geogafia Urbana em Elisée Reclus e sua época. In COELHO, P. A. (org.) Elisée Reclus. Renovação de uma cidade; Repartição dos homens. São Paulo: Expressão e Arte; Imaginário, 2010, p. 9-28.

PUMAIN, D.; PAQUOT, T., KLEINSCHMAGER, R. Dicitonnaire La ville et I'urbain. Paris : Anthropos, 2006. 
RATZEL, Friedrich. Anthropogeographie. Stuttgart : Engelhorn:1881-1891.

RONCAYOLO, Marcel. La ville et ses territoires. Paris: Gallimard, 1990.

SANTOS, Milton. Técnica, Espaço, tempo: globalização e meio técnico-científico informacional. São Paulo: Hucitec, 1994.

SASSEN, Saskia. The Global City: New York, London, Tokyo. Princeton: Princeton Univ. Press, 1991. SOJA, Edward. Postmetropolis: Critical Studies of Cities and Regions. Oxford: Blackwell, 2000.

TONNIES, Ferdinand. Communauté et société, categories fondamentales de la sociologie pure (1887). In: Ansay ; Schoonbrodt (Dir.). Penser la ville. Bruxelles: A.A.M., 1989, p.441-447.

TOPALOV, Christian et al. L'aventure des mots de la ville. Paris : Robert Laffont, 2010.

VASCONCELOS, Pedro de A. Dois Séculos do Pensamento sobre a Cidade. Salvador: Edufba; Ilhéus: Editus, 2012.

WEBER, Max. The City (1921). New York: The Free Press, 1958.

WIRTH, Louis. Le phenomène urbain comme mode de vie (1938). In: Grafmeyer: Joseph. L'Ecole de Chicago. Paris: Aubier, 1994, p.255-280

WRIGHT, Frank Lloyd. La ville evanescente. [Paris], Infolio, 2013 [1932].

ZOIDO, Florencio et al. Diccionario de geografia urbana, urbanismo y ordenación del território. Madrid: Ariel, 2000.

Submitted december 2015 Accepted january 2016 